\title{
EPSとジオグリッドの組合せによる 落石衝撃力の緩衝効果に関する実験的研究
}

\author{
加藤英樹 $1 \cdot$ 栘尾孝之 ${ }^{2} \cdot$ 千代田健 ${ }^{3} \cdot$ 村田佳久 ${ }^{4}$ \\ 津田＼cjkstart暁 5 ・福澤崇志 6 ・米原拓実7 ・前川幸次 ${ }^{8}$
}

\begin{abstract}
落石を対象とした防災構造物（ロックシェッド）上に発泡スチロール (以後, EPSとする) を積層し, 落石 衝撃力を緩和する工法が一般的に行われてきた . 落石衝撃力の緩和効果はEPS単体の積層構造で得られるが， 衝撃力が大きくなると緩和領域（EPSの設置高さ）が大きくなり施工性や経済性が悪く不合理となることから， EPSの設置高をおさえて衝撃緩衝効果を高めることのできる工法か期待されている .

本研究では, 実物大レベルの重錘落下実験によりジオグリッドを補強材として設置したEPSの衝撃緩衝効果 が従来の設計方法より向上することを確認することができた .
\end{abstract}

キーワード : ジオグリッド，衝撃緩衝，EPS，高速引張試験

\section{1.はじめに}

北海道の豊浜トンネルにおける落石事故の悲劇から， 来年で 15 年目を迎える.落石による衝撃力は非常に大 きく，一度落石事故が発生すると多大な被害を生じか ねないことから，ロックシェッドのような落石防災構 造物か数多く設置されている.また, 落石による過大 な衝撃力が予想される場合には, わか帼では, 防災構 造物上に日Sを積層することにより衝撃力を緩和する工 法が用いられてきた .しかし， PS を積層するだけで は, EPS の緩和領域 (EPS 設置高) が大きくなり，施工 性や経済性力悪く不合理となる事例も多い．

弚こで, 听の層間 (最上層下 1 層目) に引張り岡性 の高いジオグリッドを補強材として設置することで， ES の衝撃吸収力とジオグリッドの引張り強さによる補 強効果の組合せによる衝撃緩衝効果について実物大実 験を行い，光の効果を確認できた .また，ジオグリッ ドの補強効果(緩衝効果)の設計方法は, Terzaghi の支持 力理論を基本に山内らがハンモック効果を考慮して提 案した支持力算定式 ${ }^{1)}$ を参考にする.

\section{2 . 実験の概要}

本実験では , 防災構造物上のEPSとジオグリッドの組 合せによる衝撃力緩衝効果を確認する目的て図 1に示す ような， $6.0 \mathrm{~m}$ (幅) $\times 6.0 \mathrm{~m}$ (奥行き) $\times 0.2 \mathrm{~m}$ (厚さ) $の$ コンクリート土間上の, $4.0 m$ (幅) $\times 4.0 \mathrm{~m}$ (奥行き) $\times$ $21 \mathrm{~m}$ (高さ) の周囲4辺を合板で枠組みし単管で補強し た囲い壁内に，厚さ50mmの砂を敷き，単位体積重量 $15 \mathrm{~kg} / \mathrm{m} 3$ のPS (20mx $10 \mathrm{mx} 0.5 \mathrm{~m}$ ) を4.0m (幅) $\times 4.0 \mathrm{~m}$ (奥行き) $\times 20 \mathrm{~m}$ (設置高さ) で目地が重ならないよう に交互に積重ねて重錘落下実験槽を築いた .コンクリ 一ト土間の中央部付近には図-1のように土圧計を $0.25 \mathrm{~m}$ ピッチで中央から1番〜5番まで5個設置した .

補強材にはポリエチレン製，一軸延伸タイプで補強 材製品基準強度90kNnのジオグリッドと，ポリプロピレ ン製て縦27kN/m, 横30kN/m軸延伸タイプを用いた . 一軸延伸タイプのジオグリッドは2枚敷きとし, 強度発 現の方向性を考えて90度回転させて敷設した . 二軸延伸 タイプのジオグリッドは1枚敷きおよび枚敷きとした . また , 敷設位置は日S最上層下と2層目上とした . 重錘

特別会員 , 太陽工業株式会社 , 国土環境エンジニアリングカンパニー († 532-0012 大阪市淀川区木川東4-8-4) 2特別会員 , 太陽工業株式会社 , 国土環境エンジニアリングカンパニー († 154-0001東京都世田谷区池尻2-23-16) 3非会員 , 株式会社JSP , 第一事業部 建築土木資材事業部 開発部開発グループ († 100-0005東京都千代田区丸の内3-4-2 新日石ビル) 非会員 , 日本サミコン株式会社 , 企画管理部 (广950-0925新潟市中央弁天橋通1-8-23)

5非会員 , カネカケンテック株式会社 , 東日本事業部 (一 100-0011東京都千代田区内幸町1-3-3) 6非会員，積水化成品工業株式会社，第1事業本部 土木資材事業部（广306-0235茨城県古河市下辺見1336-2) 7非会員, 太陽工業ジオテクノサービス株式会社 技術開発課 († 529-0344滋賀県東浅井郡湖北北町馬渡字中之町1417) 8非会員 , 金沢大学 , 理工研究域環境デザイン学系 († 920-1192石川県金沢市角間町) 


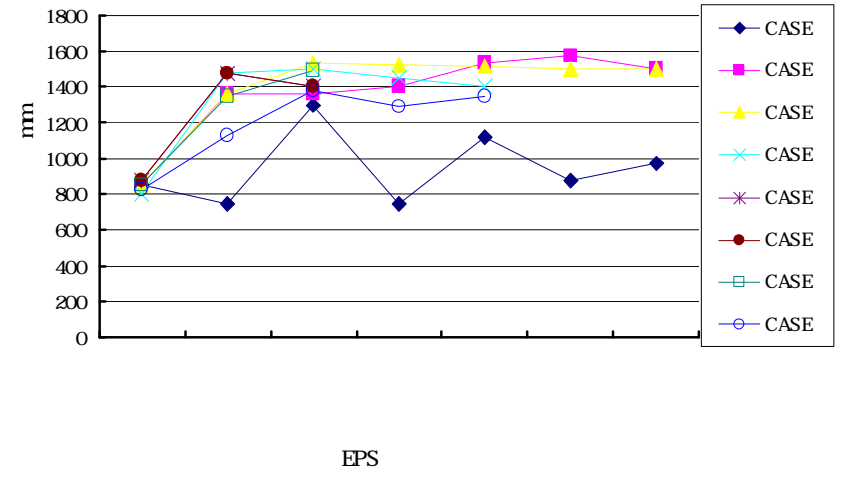

図-2 ESS各層の破断面直径

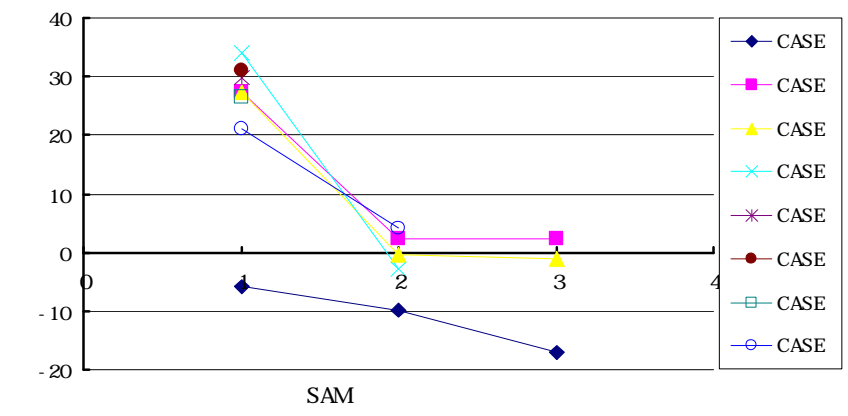

図-3 ESS各層の破断分散角度

(2) 土圧

a) 土圧の時間的変化

土圧計は, ESSの中心ら $0.25 \mathrm{~m}$ ピッチに番号 1 から 5 まで 5 個設置した . 実験ケースごとの土王測定結果を 図4に示す。

全ケースにおいて , 中心部の土圧計 1 と最外側の土 圧計 5 は关の他と比較して小さな值を示している.こ れは土圧計を設置した位置に $\mathrm{PS}$ の目地位置か重なり， 衝撃力が充分に伝達されなかったためであると考えら れる.また．CASE1では貫入開始後約 0.07 秒後に最大貫 入量に達するが, 弚の後も土圧はほぼ一定に保ちなが ら，兴の後およ光 0.03 秒後にどの土圧計も土圧の值が 急激に減少している。方, CASE2 から CASE8 て慣入 開始後約 $0.08 \sim 0.09$ 秒後に最大貫入量 (図-8参照) に 達し, 弚の前後から土圧か緩やかに減少し始めている。 土圧の立ち上がりについては, CASE1 と CASE2から CASE8 の間に差は見られない .

また，全体的な土圧の作用時間は，CASE1 が 0.1 秒強 程度に対し, CASE2 から CASE8 は 0.2 秒弱程度と 2 倍弱 の值を示し，どのケースも作用時間は中心から遠い土 圧計に従い短くなる傾向が見られるものの顕著なもの ではない。

これはジオグリッドによる吊り上げ効果 (ハンモッ ク効果) により, 重錘の落下とリバウンドに伴う荷重 の載荷と除荷が重鍾の直下に作用せず， ES 内部で分散 したことによる影響であるものと考えられる。
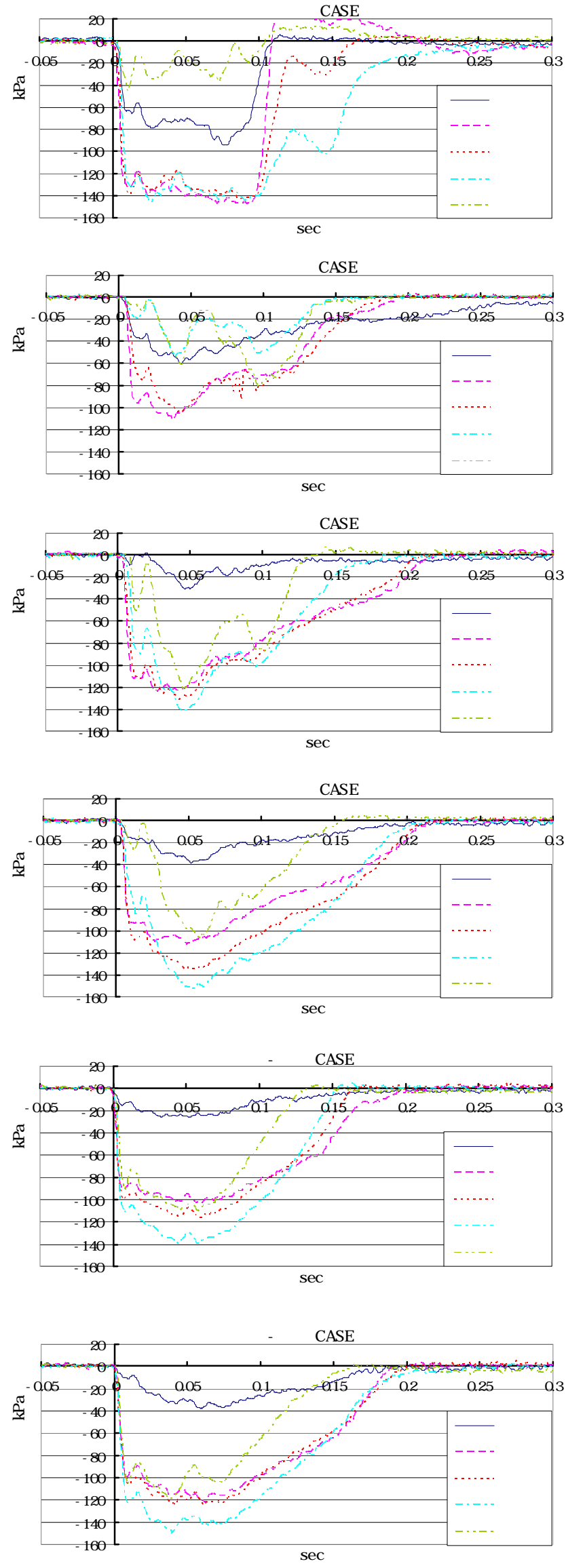

図-4a 各ケースの土圧グラフ (光の1) 

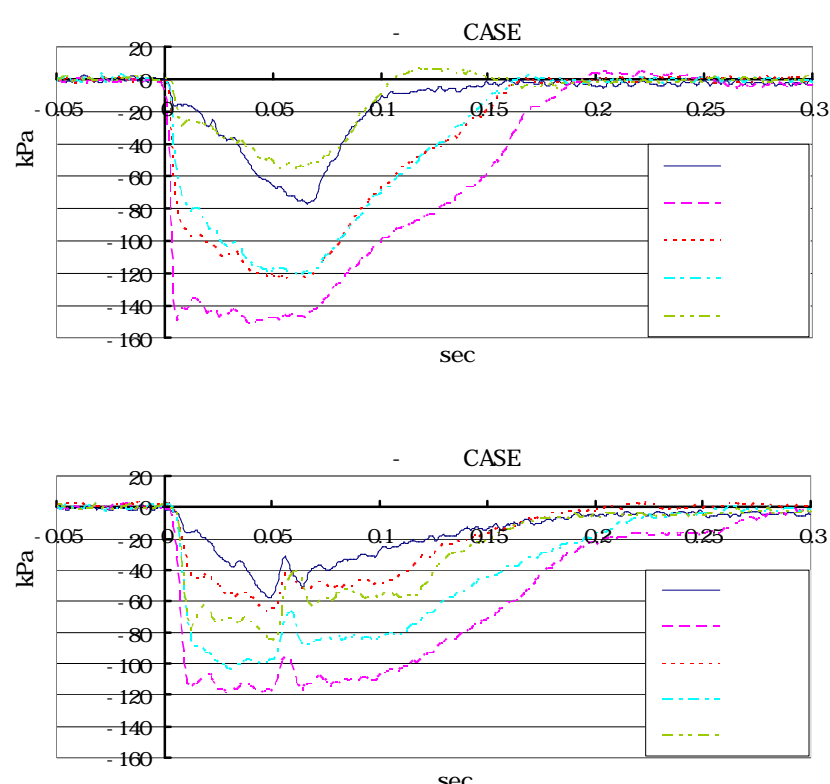

图-4b 各ケースの土圧グラフ (弚の 2)

\section{b) 最大土圧と平均土圧の分布}

表-3 は各土圧計の最大土圧の值を示し，表-4 は各土 圧計の平均土圧を示す. また，図 5 およひ図 6 はこれ らをグラフ化したものである .

表-3 各ケースの最大土圧 (単位: $\mathrm{kPa}$ )

\begin{tabular}{|c|c|c|c|c|c|}
\hline 土王計番号 & 1 & 2 & 3 & 4 & 5 \\
\hline 中心距離 & 0 & $0.25 \mathrm{~m}$ & $0.50 \mathrm{~m}$ & $0.75 \mathrm{~m}$ & $1.00 \mathrm{~m}$ \\
\hline CASE1 & -94.6 & -147.6 & -139.8 & -144.0 & -36.2 \\
\hline CASE2 & -60.4 & -111.2 & -104.1 & -54.4 & -31.2 \\
\hline CASE3 & -30.7 & -124.0 & -125.8 & -122.1 & -88.2 \\
\hline CASE4 & -38.4 & -111.5 & -136.0 & -152.4 & -106.5 \\
\hline CASE5 & -25.8 & -102.1 & -115.4 & -139.6 & -109.6 \\
\hline CASE6 & -37.2 & -116.2 & -122.7 & -141.6 & -104.7 \\
\hline CASE7 & -76.7 & -147.3 & -122.9 & -121.9 & -55.0 \\
\hline CASE8 & -38.2 & -118.5 & -58.6 & -103.8 & -74.0 \\
\hline
\end{tabular}

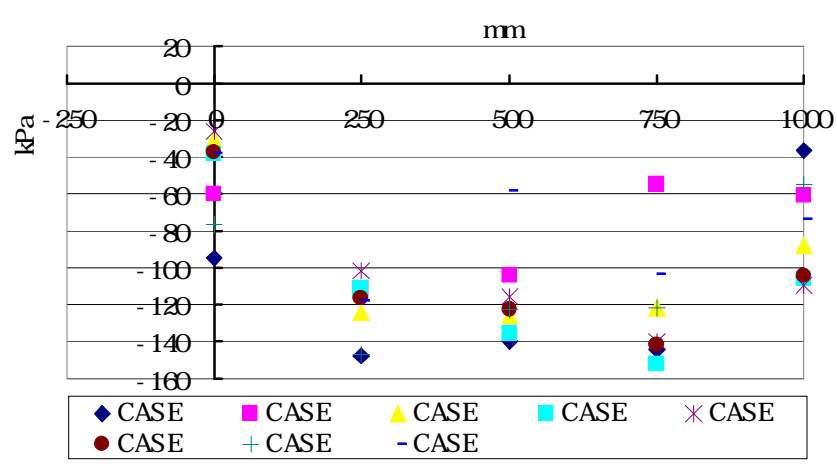

図-5 各ケースの最大土圧グラフ
表-4 各ケースの平均土圧 (単位 : $\mathrm{kPa}$ )

\begin{tabular}{|c|c|c|c|c|c|}
\hline 土土計番号 & 1 & 2 & 3 & 4 & 5 \\
\hline 中心距離 & 0 & $0.25 \mathrm{~m}$ & $0.50 \mathrm{~m}$ & $0.75 \mathrm{~m}$ & $1.00 \mathrm{~m}$ \\
\hline CASE1 & -46.9 & -87.0 & -100.2 & -119.8 & -11.5 \\
\hline CASE2 & - & - & - & - & - \\
\hline CASE3 & -14.0 & -104.8 & -107.0 & -102.2 & -70.3 \\
\hline CASE4 & -24.6 & -95.6 & -113.2 & -115.7 & -63.2 \\
\hline CASE5 & - & - & - & - & - \\
\hline CASE6 & -28.0 & -110.3 & -115.7 & -136.0 & -101.8 \\
\hline CASE7 & -48.8 & -145.9 & -112.2 & -105.5 & -42.2 \\
\hline CASE8 & - & - & - & - & - \\
\hline
\end{tabular}

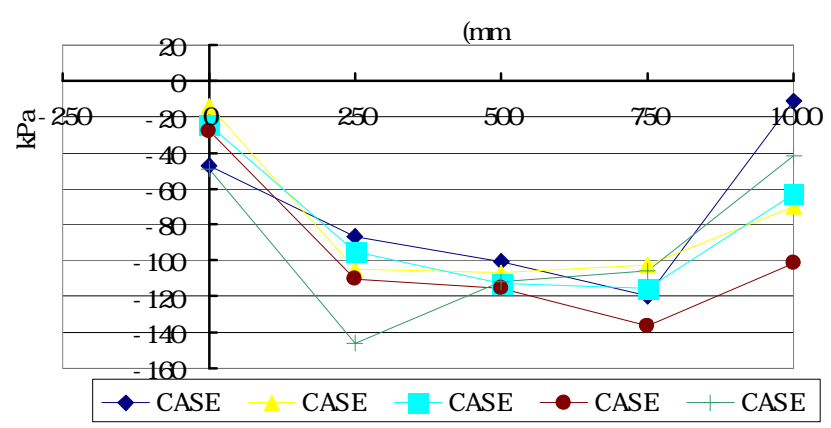

図-6 各ケースの平均土圧グラフ

土圧の分布範囲について考えると, 最大土圧, およ び平均土圧とも CASE1 では土圧計 1〜4 までの值と比較 し, 土圧計 5 の值は極端に小さい.このことから半径 の約 $0.75 \mathrm{~m}$ から $100 \mathrm{~m}$ 以内の範囲で大きな土圧を受けた と推定できる.これは，重鍾の1辺長 0.78mの約 10か ら 13 倍であり，前述の ES 破断直径と破断分散角度よ り CASE1 の 2 層目以下での重錘 1辺長の約 1 1 1 4 倍 とおおよ光合致する .

CASE2から CASE8について, 土圧計 1〜4まての值と比 較して土圧計 5 の值の下がり方も小さい.このことか ら, 直径約 $15 \mathrm{~m}$ 以上の範囲で力を受けていることがわ かる. CASE1 と同樣に ESS 破断直径と破断分散角度より 破断面の直径約 15mと合致する．したがって，CASE1 では重鍾の衝撃による衝撃力の範囲は ESSの破断径と一 致し , 大きな広がりを見せないが， CASE2 から CASE8 で は衝撃力の範囲， ESS の破断径ともに CASE1 より大きな 広があり，補強材による分散効果を見ることができる．

c) 衝撃力 - 貫入量

測定した重錘の加速度に重錘質量を乗じた値を重錘 衝撃力とし , 衝突速度と重鍾加速度の 2 階積分から得 られる重錘変位を貫入量とする．

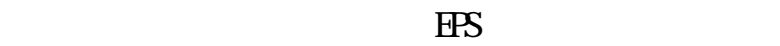
生する。ES の圧縮式験による応力。 とひずみ量％の関 係に加え，応力 $\sigma$ と衝撃力か作用する面積 A の積を衝 
撃力 $\mathrm{P}$ とし，ひずみ量を貫入量と置き換えると，ひず み量と応力，作用面積から衝撃力と貫入量の関係をモ デル化することができる . 図-7 にモデル化した曲線を 示す。さらにモデル化する方法についての詳細を以下 にまとめる .

各ケースの実験結果のグラフ上に , 今回の実験で得 られた各層下面の分散面積は全て同じと見なすことが できることから $A_{1}=A_{2}=A_{3}=A_{4}$ とし， ES の 5\%ひずみ に相当する貫入量 $C_{5}\left(C_{5}=2000 \times 0.05=100 \mathrm{~mm}\right)$ に対す る衝撃力を $P_{5}=\sigma_{5} \cdot A_{1}$ とする .

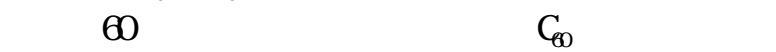

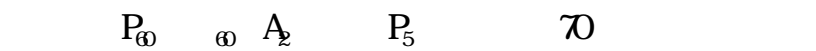
する貫入量 $C_{00}$ まで直線を延長する .この点での衝撃力 を $\mathrm{P}_{70}$ とし , さらに貫入量が 㫙厚さ $\mathrm{h}\left(\mathrm{C}_{10}=2000 \mathrm{~mm}\right)$ の $80 \%$ に対する衝撃力を $P_{80}=\sigma_{80} \cdot A_{4}$ として $P_{70}$ と結ぶ .

したがって，モデルでは曲線の下側の面積は衝撃の エネルギー量と ESSに変形を与える仕事量と等価である と考える

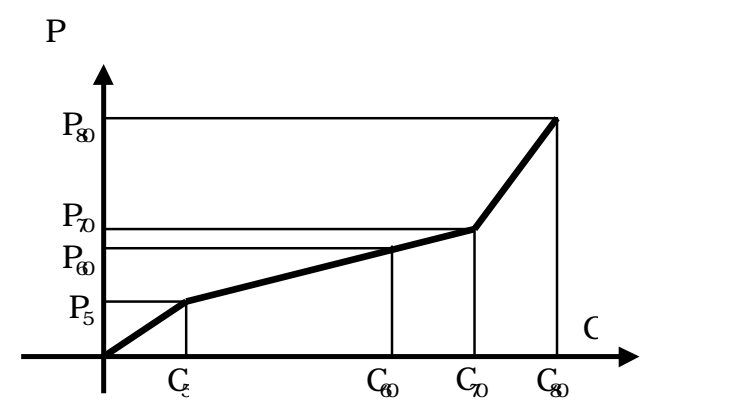

図-7 衝撃力-貫入量図モデル化曲線

このようにして得られた衝撃力と貫入量のモデル線 と実験で得られた衝撃力と貫入量の波形と重ね合わせ た代表的な図を図-8に示す．実験で得られた実線とモ デル化した破線を比較することで衝撃力と貫入量の関 係の整合性について論じることができる .

横長のグラフ形状の場合は衝撃力に伴う貫入量が大 きいことを示し , グラフの形状か縦長の場合は衝撃力 が大きく貫入量がささいことを示すことになる．

このグラフを利用して EPS の必要厚さ (敷厚) を決 める .

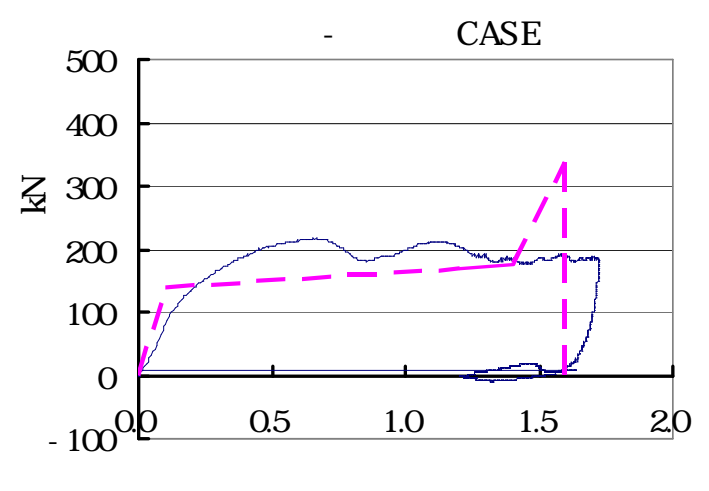

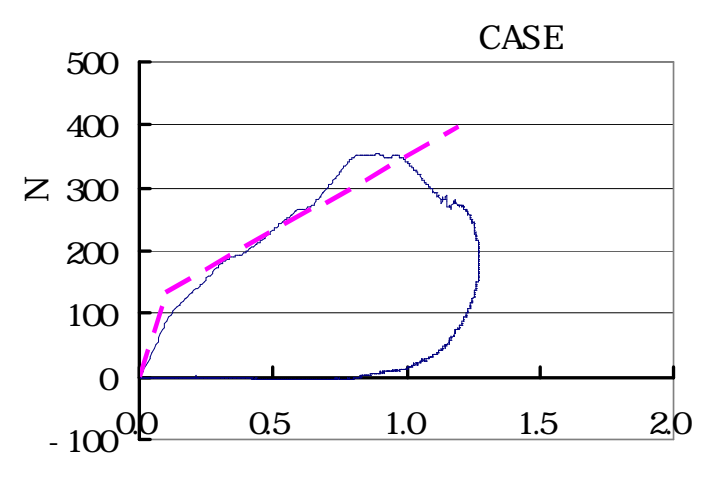
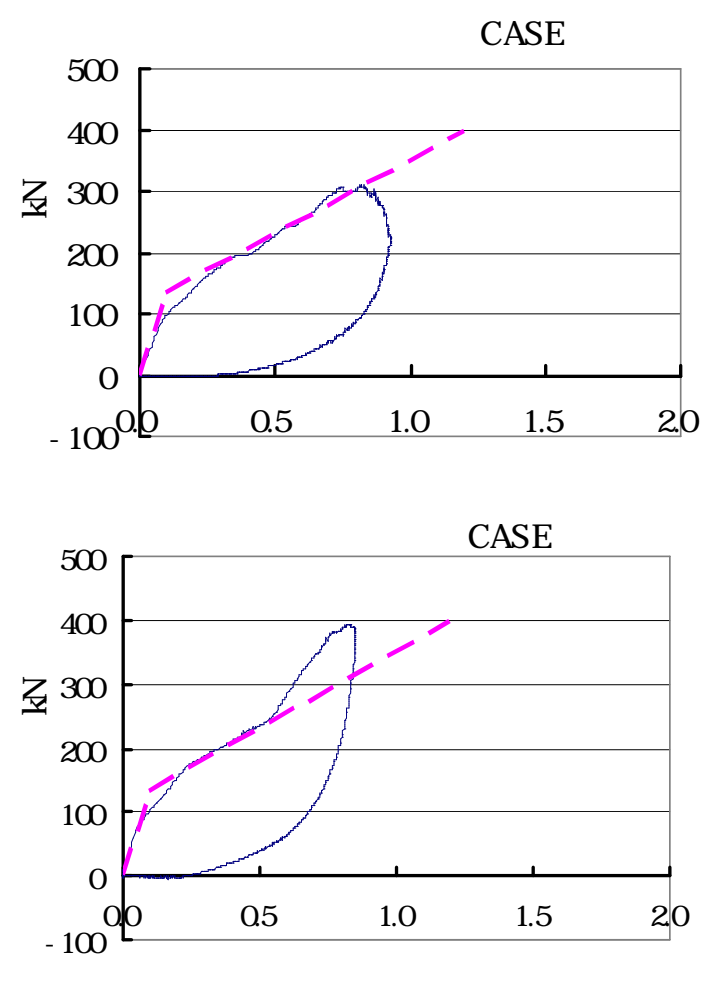

図-8 衝撃力-貫入量図

CASE1 では，ひずみが 70\%を超えた時点て実際の波形 とモデル線とずれか甡じているが， CASE3 から CASE7 で は , 想定したモデル線とよく一致している .

以上のことから，本実験の ES とジオグリッドの組合 せによる衝撃力緩和法においても，従来の日S単体での 衝撃力緩和法の設計方法 ${ }^{4}$ を用いても問題無いこととし た。

さらに ES とジオグリッドとを併用した CASE3 から CASE7 では無補強の CASE1 に比べて衝撃力は大きくなる が貫入量が小さくなることがわかる .これはジオグリ ッドと ESの組み合わせによる荷重の分散効果力現れた ものと考えられる .

\section{4 .ジオグリッドの選定検討への実験成果の反映}

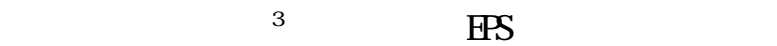
力の緩衝効果は高いものの，衝撃力の分散効果はあま り期待できないことがわかっている . 本実験によりジ 
オグリッドは衝撃力を があることがわかった . 本実験成果をジオグリッドの 選定検討に反映させるためジオグリッドの補強効果に ついて考察する . また, 落石による衝撃力の分散効果 のモデル図を図-9ニ示す .

ESブロックは柔軟な材質の材料であることから， Terzaghi の支持力理論を基本とした山内らか提案した支 持力算定式のハンモック効果による設計法1) 基に衝撃 力の分散効果を表す計算モデルを立てる .

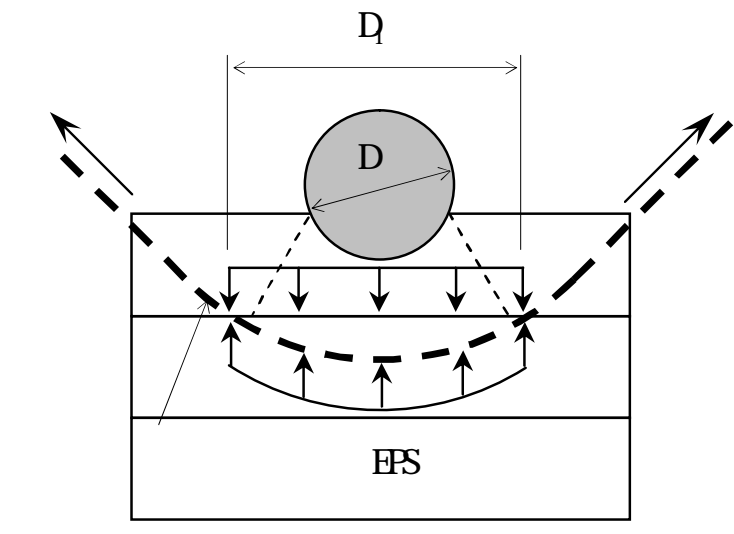

図-9 衝撃力の分散効果の検討モデル図

落石による衝撃力とジオグリッドに発生する張力と ESブロックの支持力については次の通りとなる .

a) 単位面積当たりに生じる衝撃力

単位面積あたりの衝撃力：Pは，衝撃力：Pを2段目の ESブロック上面の予想破断面積 : $A_{1}$ て除すことにより 求められる.しかし, 破断面積は落石の直径に依存す るので, 予想破断直径 : Dは次式のように算定する .

$$
\mathrm{D}_{1}=\mathrm{D}+2 \times \lambda \times \tan 30^{\circ}
$$

ここに, Dは落石の予想直径,$\lambda$ はEPS最上層厚さ， $\tan 30^{\circ}$ はEPS破断径と分散角度て述べたように実験結果 よりEPS破断径が約25度から約35度であったため、30度 とする .

次に, ジオグリッドに作用する衝撃力を等分布荷重 として奥行き1 On当りの衝撃力 : P $\mathrm{P}$ として換算すると

$$
\mathrm{P}_{\mathrm{V}}=\mathrm{P}_{\mathrm{D}} \times \mathrm{D}_{1}
$$

となる．

b ) 『Sブロックの支持力

ESブロックの支持力 : $Q$ \&はPSブロックの耐圧性能で 表すことができる .

ESブロック密度 $15 \mathrm{~kg} / \mathrm{m}$ の耐圧性能は, 本実験結果よ り70\%ひずみ時の圧縮強度 : q (300kN/min) 程度とした .

$$
\mathrm{Q}=\mathrm{q} \times \mathrm{D}
$$

c ) ジオグリッドに発生する張力

ジオグリッドに作用する張力：Tの鉛直成分：T、は次 式で表すことができる .

$$
\mathrm{T}_{\mathrm{V}}=2 \mathrm{~T} \sin \theta / \mathrm{D}_{1}
$$

ここで, EPSブロックへのめり込み量より求まるジオ グリッドの水平方向からの角度を図-10に示す . $\mathrm{D}_{1}$ : 落 石の予想破断直径, $\theta$ : ジオグリッドの引張り方向の水 平方向からの角度である。

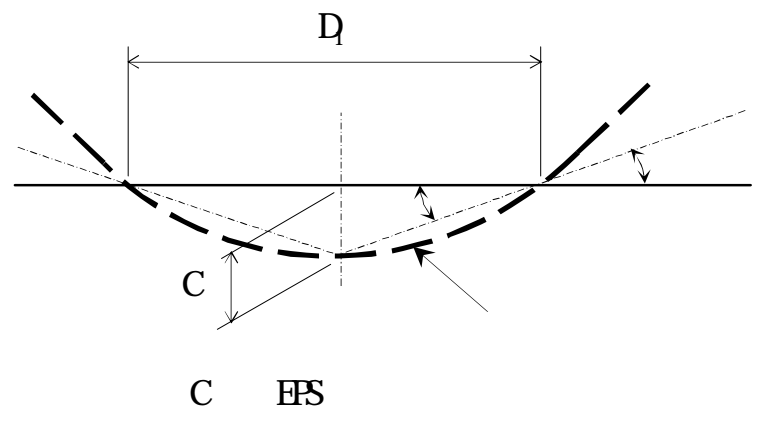

図-10 ジオグリッドの角度成分図

ESへのめり込み量は , 過去の実験報告書の設計法"3) から次式で算定できる.

$$
\mathrm{C}=2 \times \mathrm{W} \times \mathrm{H} /\left(\mathrm{P}+\mathrm{P}_{5}\right)+0.05 \times \mathrm{h}
$$

となる

ここに, W: 落石重量, H: 落下高さ, h: 巴PSブロック の敷厚，P: 衝撃力，また過去の実験報告書 ${ }^{3)}$ より $\mathrm{P}_{5}$ : $\sigma_{5} \times$ Aとし、 $\sigma_{5}=0.008(\mathrm{~N} / \mathrm{mm} 2)$ を用いる.

よって , 基本となる力の釣り合い式は次式となる．

$$
\mathrm{P}_{\mathrm{V}}=\mathrm{T}_{\mathrm{V}}+\mathrm{Q}=\left(2 \mathrm{~T} \times \sin \theta / \mathrm{D}_{1}\right)+\mathrm{Q}
$$

ここで, 引張力 Tについて解くと次式となる .

$$
\mathrm{T}=\left[\mathrm{D}_{1} \times\left(\mathrm{P}_{\mathrm{V}}-\mathrm{Q}\right)\right] /(2 \times \sin \theta)
$$

以上より，ジオグリッドに作用する引張強度を算定す ることができる .

\section{d ) ジオグリッドの速度依存性}

ジオグリッドの引張強度の評価には引張速度による 速度依存性がある . 本実験に用いたジオグリッドの引 張強度は補強土工法で用いる場合の強度試験方法で得 られた強度である . 落石の衝撃力は極めてわずかな時 間でジオグリッドに載荷されるため, 引張強度の評価 に速度依存性による時間効果を与えることを考えた． 弚こで，表-5に示す載荷速度で高速引張試験を同速度で 回行い, 乥れぞれのデータをもとに引張速度と載荷速 度の近似式 (1次方程式) を求め, 各載荷速度における 強度の比率を求めてジオグリッドの基準強度の割増し 係数を求めることにした . 
表- 5 高速引張試験ケース

\begin{tabular}{|c|c|}
\hline 引張式験機 & SHIMADZU EHF-U2H-2DL \\
\hline 載荷速度 & 補強材製品基準強度 \\
\hline $0.1 \mathrm{~m} / \mathrm{sec}$ & $90 \mathrm{kN} / \mathrm{m}$ \\
\hline $0.5 \mathrm{~m} / \mathrm{sec}$ & $90 \mathrm{kN} / \mathrm{m}$ \\
\hline $1.0 \mathrm{~m} / \mathrm{sec}$ & $90 \mathrm{kN} / \mathrm{m}$ \\
\hline $5.0 \mathrm{~m} / \mathrm{sec}$ & $90 \mathrm{kN} / \mathrm{m}$ \\
\hline $10.0 \mathrm{~m} / \mathrm{sec}$ & $90 \mathrm{kN} / \mathrm{m}$ \\
\hline
\end{tabular}

載荷速度は，今回新たに試験を行った表一5と，載荷速 度20\%/min（速度換算0.00162n/sec）て過去に行った試 験データを用いた . また， 5.0m/sec以上のデータについ ては，最大荷重付近で荷重値の増减が見られたため，10 点, 20 点, 30点移動平均を求め最も安全側の30点移動平 均を採用した . 試験值と直線近似による最大荷重を表- 6 に示す．なお，載荷速度15.0ndsec以上については試験 值の外插により求めて示した .さらに, 荷重時間曲線 の例を図-11に示し, 載荷速度と引張強度の関係を図 12 に示す。

表- 6 載荷速度と最大荷重比率関係表

\begin{tabular}{|c|c|c|c|c|c|c|c|c|}
\hline \multirow{3}{*}{$\begin{array}{l}\text { 載荷 } \\
\text { 速度 } \\
\text { (m/sec) }\end{array}$} & \multicolumn{2}{|c|}{$\begin{array}{c}\text { 測定最大 } \\
\text { 荷重 } \\
(\mathrm{kN})\end{array}$} & \multicolumn{2}{|c|}{$\begin{array}{c}10 \text { 点移動平 } \\
\text { 均最大何重 } \\
k \mathrm{~N})\end{array}$} & \multicolumn{2}{|c|}{$\begin{array}{c}\text { 20点移動平 } \\
\text { 均最大何重 } \\
k \mathrm{~N})\end{array}$} & \multicolumn{2}{|c|}{$\begin{array}{c}\text { 30点移動平 } \\
\text { 均最大何重 } \\
k \mathrm{~N})\end{array}$} \\
\hline & \multicolumn{2}{|c|}{$\begin{aligned} y & =0.1027 x \\
& +2.282\end{aligned}$} & \multicolumn{2}{|c|}{$\begin{aligned} y=0.1014 x \\
\\
+2.282\end{aligned}$} & \multicolumn{2}{|c|}{$\begin{aligned} y=0.0974 x \\
+2.282\end{aligned}$} & \multicolumn{2}{|c|}{$\begin{aligned} y & =0.0924 x \\
& +2.282\end{aligned}$} \\
\hline & 引張強度 & 比率 & 引張強度 & 比率 & 引張強度 & 比率 & 引張強度 & 比率 \\
\hline 0.00162 & 2.2822 & 1.00 & 2.2822 & 1.00 & 2.2822 & 1.00 & 2.2821 & 1.00 \\
\hline 0.1 & 2.5355 & 1.11 & 2.5355 & 1.11 & 2.5355 & 1.11 & 2.5355 & 1.11 \\
\hline 0.5 & 2.5500 & 1.12 & 2.5500 & 1.12 & 2.5500 & 1.12 & 2.5500 & 1.12 \\
\hline 1.0 & 2.6520 & 1.16 & 2.6520 & 1.16 & 2.6520 & 1.16 & 2.6520 & 1.16 \\
\hline 5.0 & 3.1250 & 1.37 & 3.0955 & 1.36 & 3.0180 & 1.32 & 2.9245 & 1.28 \\
\hline 10.0 & 3.0690 & 1.34 & 3.0645 & 1.34 & 3.0540 & 1.34 & 3.0385 & 1.33 \\
\hline 15.0 & 3.8225 & 1.67 & 3.8030 & 1.67 & 3.7430 & 1.64 & 3.6680 & 1.61 \\
\hline 20.0 & 4.3360 & 1.90 & 4.3100 & 1.89 & 4.2300 & 1.85 & 4.1300 & 1.81 \\
\hline 25.0 & 4.8495 & 2.12 & 4.8170 & 2.11 & 4.7170 & 2.07 & 4.5920 & 2.01 \\
\hline 30.0 & 5.3630 & 2.35 & 5.3240 & 2.33 & 5.2040 & 2.28 & 5.0540 & 2.21 \\
\hline
\end{tabular}

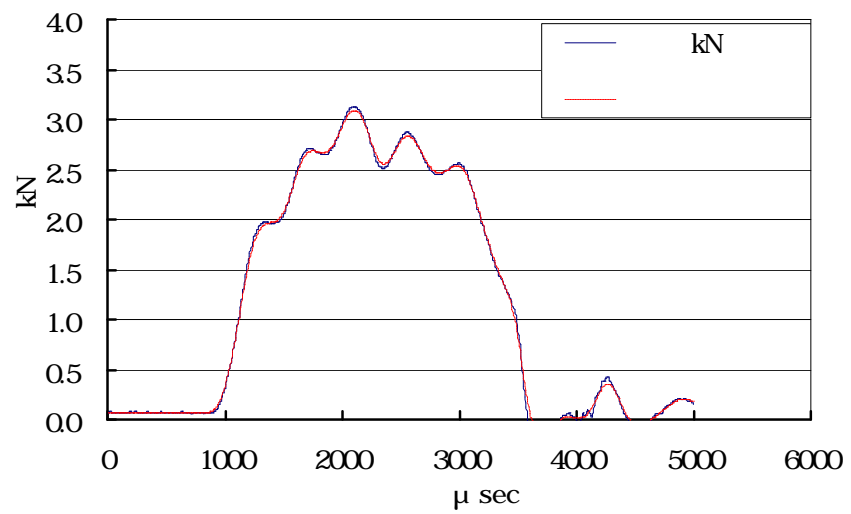

図-11 荷重時間曲線グラフ

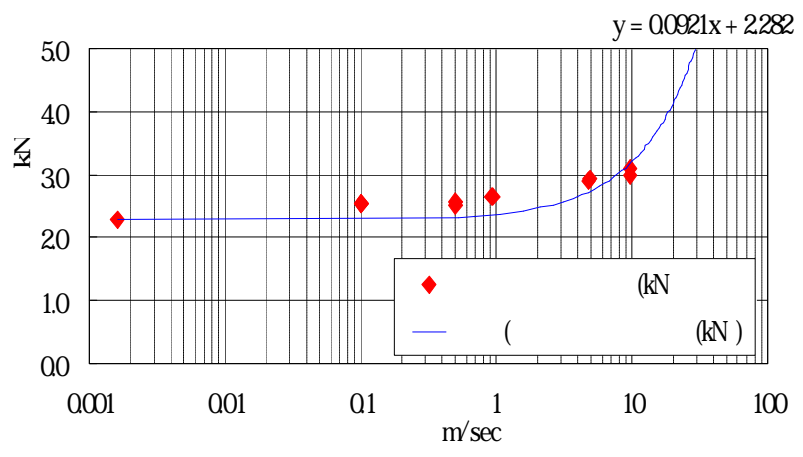

図-12 載荷速度と引張強度の関係グラフ

速度依存性による強度比率をみると載荷速度 25. On/secて約2倍になるが, 落石の落下速度は過去の実 積等から10.0 30. Ondsecの落下速度が多く，実験デー タの外挿値を用いることは危険であるため，試験結果 を参考に, 補強材製品基準強度の割り増し係数を15と した .よって , ジオグリッドの必要強度は, 次式のよ うに算定できる .

$$
\mathrm{T} \leq \mathrm{T} \max \times 1.5
$$

ここで, $\mathrm{T}$ : 引張力 , Tnax : 各補強材の製品基準強度 とする

\section{5 . 設計検討のまとめ}

本実験で得られた結果をもとに試算した衝撃力と曰S ブロックの敷厚 , ジオグリッドの必要強度を表-7に示す． さらに, EPSとジオグリッドの組合せによる落石衝撃 力の緩衝効果として得られた特徵的な事項と衝撃緩衝 工の設計検討の結果を，従来工法と比較する形で以下 にまとめる .

1 ) 甲Sとジオグリッドを組み合わせた場合でも衝撃吸 収効果の設計には従来のEPS単体での衝撃力緩和法 で用いられた設計法を用いて日Sの敷厚を決める。

2 ) 今回の実験結果より試算したESの敷厚を比較する と, 従来のEPS単体に比べتSの敷厚が層 $(50 \mathrm{~cm})$ から3層 $(150 \mathrm{~cm})$ 減らすことかできる.特に落下高 さか高くなるに従い必要敷厚の差が大きくなる。

3 ) 重鍾落下実験の加速度測定結果とEPS破断面の直径 計測結果からジオグリッドを敷設することで円S単 体時よりも衝撃力については，14倍から2 2 倍程度 大きくなる . 同時にジオグリッドによる荷重の分 散効果て設計分散幅力従来に比べ大きく設定でき 貫入量は小さくなる .

4 ) ジオグリッドは一般的な引張強度の材料を使用す ることができる．一軸延伸タイプのジオグリッド を使用する場合は直交方向に2枚重ねる。 
表- 7 従来工法との比較表

\begin{tabular}{|c|c|c|c|c|c|c|c|c|c|}
\hline \multirow{3}{*}{$\begin{array}{l}\text { 落石 } \\
\text { 重量 }\end{array}$} & \multirow{3}{*}{ 比較 } & \multicolumn{8}{|c|}{ 落下高さ } \\
\hline & & \multicolumn{2}{|c|}{$10.0 \mathrm{~m}$} & \multicolumn{2}{|c|}{$20.0 \mathrm{~m}$} & \multicolumn{2}{|c|}{$30.0 \mathrm{~m}$} & \multicolumn{2}{|c|}{$40.0 \mathrm{~m}$} \\
\hline & & $\begin{array}{c}\text { 敷厚 } \\
\text { (m) }\end{array}$ & $\begin{array}{c}\text { 衝擊力 } \\
\text { (kN) }\end{array}$ & $\begin{array}{c}\text { 敷厚 } \\
\text { (m) }\end{array}$ & $\begin{array}{c}\text { 衝撃力 } \\
\text { (kN) }\end{array}$ & $\begin{array}{c}\text { 敷厚 } \\
\text { (m) }\end{array}$ & $\begin{array}{c}\text { 衝撃力 } \\
(\mathrm{kN})\end{array}$ & $\begin{array}{c}\text { 敷厚 } \\
\text { (m) }\end{array}$ & $\begin{array}{c}\text { 衝撃力 } \\
\text { (kN) }\end{array}$ \\
\hline \multirow{2}{*}{$\begin{array}{l}10 \\
k N\end{array}$} & 従来 & 1.0 & 212 & 2.0 & 216 & 2.5 & 226 & 3.5 & 230 \\
\hline & 新規 & $\begin{array}{l}1.0 \\
(90)\end{array}$ & 352 & $\begin{array}{l}1.0 \\
(90)\end{array}$ & 468 & $\begin{array}{c}1.5 \\
(90)\end{array}$ & 483 & $\begin{array}{l}2.0 \\
(90)\end{array}$ & 502 \\
\hline \multirow{2}{*}{$\begin{array}{l}20 \\
k N\end{array}$} & 従来 & 1.5 & 328 & 2.5 & 352 & 3.5 & 363 & 4.5 & 369 \\
\hline & 新規 & $\begin{array}{c}1.0 \\
(90)\end{array}$ & 528 & $\begin{array}{l}1.5 \\
(90)\end{array}$ & 639 & $\begin{array}{c}2.5 \\
(90)\end{array}$ & 631 & $\begin{array}{l}3.0 \\
(90)\end{array}$ & 667 \\
\hline \multirow{2}{*}{$\begin{array}{l}30 \\
\mathrm{kN}\end{array}$} & 従来 & 1.5 & 544 & 2.5 & 482 & 4.0 & 480 & 5.0 & 493 \\
\hline & 新規 & $\begin{array}{c}1.0 \\
\text { (112) }\end{array}$ & 442 & $\begin{array}{l}2.0 \\
(90)\end{array}$ & 759 & $\begin{array}{c}3.0 \\
(90)\end{array}$ & 778 & $\begin{array}{c}3.5 \\
\text { (90) }\end{array}$ & 831 \\
\hline \multirow{2}{*}{$\begin{array}{l}40 \\
\mathrm{kN}\end{array}$} & 従来 & 1.5 & 710 & 3.0 & 566 & 4.5 & 574 & 5.5 & 596 \\
\hline & 新規 & $\begin{array}{c}1.5 \\
(90)\end{array}$ & 543 & $\begin{array}{c}2.5 \\
\text { (112) }\end{array}$ & 846 & $\begin{array}{c}3.0 \\
(141.9)\end{array}$ & 943 & $\begin{array}{c}4.0 \\
(141.9)\end{array}$ & 957 \\
\hline \multirow{2}{*}{$\begin{array}{l}50 \\
\mathrm{kN}\end{array}$} & 従来 & 2.0 & 752 & 3.0 & 683 & 4.5 & 695 & 6.0 & 701 \\
\hline & 新規 & $\begin{array}{c}1.5 \\
(170)\end{array}$ & 880 & $\begin{array}{c}2.5 \\
(170)\end{array}$ & 993 & $\begin{array}{c}3.5 \\
(170)\end{array}$ & 1045 & $\begin{array}{c}4.5 \\
(170)\end{array}$ & 1075 \\
\hline
\end{tabular}

※（）内の数字はジオグリッドの補強材製品基強度 Tnæx (kN/m) を示す.一軸延伸ジオグリッドを使 用する場合は，直交方向に2枚重ねて敷設する．

6 .おわりに

本実験の結果 , 巴PSとジオグリッドとを組み合わせる ことで円S内部に生じるジオグリッド荷重の分散効果に
より，無補強の場合に比べて衝撃力は大きくなるが貫 入量が小さくなり巴估の敷厚を減じることが可能となる． 施工性や経済性において非常に有効的な結果であり 合理的な設計を行うことができる .

本実験では巴Sとジオグリッドとの間に生じる層間摩 擦の要因について考慮せず, ジオグリッドと巴SSとの摩 擦か十分に取れるものとした . 今後 , ESSとジオグリッ ドとの層間摩擦の検証を行うことで，より合理的な設 計法を確立することか求められる .

謝辞 : 本実験を実施するにあたり，SAM協会各委員会の 委員各位および株式会社太野興業に多大な支援を頂い た .ここに記して深謝し上げます．

\section{参考文献}

1）土木研究センター : ジオテキスタイルを用いた補強土の 設計・施工マニュアル (改訂版) p. 237 , 2000.2

2) W. Gerber : Guideline for the approval of rockfall protection kits, SAEFL and the Swiss Federal Research Institute, 2001.

3） SAM協会 : 発泡スチロールの落石による衝撃力の緩衝効果 に関する実験報告書 , 1990.2

4) SAM協会 : SAM工法設計・施工マニュアル , 19984.

\title{
EXPERIMENTAL STUDY ON BUFFERING EFFECT OF LAYER-BUILT EPS
}

\author{
REINFORCED WITH GEOGRIDS AGAINST ROCKFALL IMPACT
}

\author{
Hideki KATOH, Takayuki MASUO, Takeshi CHIYODA, Yoshihisa MURATA \\ Satoshi TSUDA, Takashi FUKUZAWA, Takumi YONEHARA, Koji MAEGAWA
}

Expanded Poly-Styrene, i.e. EPS is heaped up on a rockfall protection structure such as a rockshed, and the layer-built EPS has a good effect on defusing the impact force of a rockfall. The thickness of layer-built EPS must not be increased in proportion to the magnitude of a rockfall,since the workability and economical efficiency become bad and irrational in case of a huge rockfall. In order to improve the performance of layer-built EPS weight free-fall tests were carried out on the layer-built EPS reinforced with Geogrids which were put between the EPS layers. It was found in this investigation that the layer-built EPS reinforced with Geogrids has a good performance against rockfalls. 